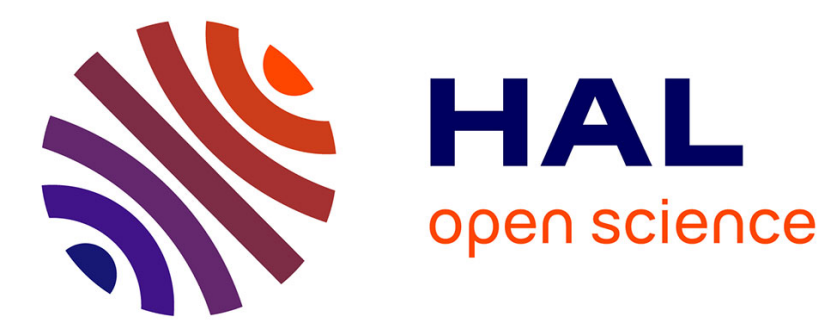

\title{
Secondary Ion Mass Spectrometry for Biological Applications
}

\author{
Dirk Schaumlöffel
}

\section{To cite this version:}

Dirk Schaumlöffel. Secondary Ion Mass Spectrometry for Biological Applications. Journal of Analytical Atomic Spectrometry, 2020, 35 (6), pp.1045-1046. 10.1039/D0JA90020F . hal-03049380

\section{HAL Id: hal-03049380 \\ https://hal-univ-pau.archives-ouvertes.fr/hal-03049380}

Submitted on 9 Dec 2020

HAL is a multi-disciplinary open access archive for the deposit and dissemination of scientific research documents, whether they are published or not. The documents may come from teaching and research institutions in France or abroad, or from public or private research centers.
L'archive ouverte pluridisciplinaire HAL, est destinée au dépôt et à la diffusion de documents scientifiques de niveau recherche, publiés ou non, émanant des établissements d'enseignement et de recherche français ou étrangers, des laboratoires publics ou privés. 


\section{Secondary Ion Mass Spectrometry for Biological Applications"}

Dirk Schaumlöffel

CNRS / Université de Pau et des Pays de l'Adour / E2S UPPA, Institut des Sciences Analytiques et de PhysicoChimie pour l'Environnement et les Matériaux, UMR 5254, 64000 Pau, France ; dirk.schaumloeffel@univpau.fr

\#Accepted manuscript :

Schaumlöffel, D. (2020), Secondary Ion Mass Spectrometry for Biological Applications.

J. Anal. At. Spectrom., 35, 1045-1046, https://doi.org/10.1039/D0JA90020F

With this brief editorial, I want to introduce the themed collection on Secondary lon Mass Spectrometry (SIMS) for Biological Applications. The selected articles of this collection are highlighting one major feature of SIMS applied to biology: the ability to acquire high-resolution element and molecule specific images of cells and tissues. Many readers of JAAS are probably more familiar with the technique of Laser Ablation (LA) ICP-MS for generation of elemental images from biological tissues; therefore, this themed collection aims to introduce SIMS, which is an atomic spectrometry technique, too, as important tool for bioimaging.

Imaging and imaging techniques are a steadily growing field of high interest in science. This great success is surely conditioned by the fact that we as humans are much more perceptive when information is visualized. For example, this is expressed by the well-known saying that "a picture is worth a thousand words". Indeed, images allow us a quick absorption of large amounts of data. Already in the dawn of humankind, men used images such as cave paintings as an effective way to communicate abstract and concrete information. In science, visual observation has always been an important way to acquire new knowledge followed by its transmission with the help of images. Therefore, the development of light microscopes in the $16^{\text {th }}$ and $17^{\text {th }}$ century was a major milestone in order to get insights into the microworld. From the beginning, researchers used these new tools for observation of biological organisms. This first bioimaging led to the early description of biological cells, recorded by Robert Hook's drawings in Microscopia (1665). Nowadays, powerful electron microscopes, notably transmission electron microscopes (TEM), allow the imaging of subcellular structures and small objects such as viruses. Highresolution TEM with correction of spherical aberrations can achieve a resolution down to $0.08 \mathrm{~nm}$ enabling even the visualization of atoms.

Although light and electron microscopy give already fascinating insights into small biological structures on micro and nanometer level, there is a considerable interest to combine this structural information with chemical information. The question is How to obtain information on the presence and the quantity of chemical elements including their isotopes as well as molecules in each pixel of an image? For example, TEM can be combined with energy-dispersive X-ray spectroscopy (TEM/X-EDS) preserving almost the high resolution of TEM alone but with element sensitivity only in the percentage range and no possibility of isotope analysis. On the other side, LA ICP-MS provides high element sensitivity at low $\mu \mathrm{g} / \mathrm{kg}$ level but only low spatial resolution at the micrometer level, which is not sufficient for subcellular imaging. The gap between these two opposite possibilities is filled by the SIMS techniques. In SIMS imaging a primary ion beam is scanning the sample surface and generating secondary ions of the chemical elements or molecules which are subsequently analyzed by a mass spectrometer. SIMS provides high spatial resolution down to 50-100 nm sufficient for the observation of subcellular structures combined with element sensitivity at the $\mathrm{mg} / \mathrm{kg}$ level as well as the possibility of isotope analysis. 
The present themed collection provides to the reader three review articles and six research papers from different application fields of SIMS bioimaging. Notably, the tutorial and critical reviews of this collection are presenting and comparing different SIMS techniques. A first tutorial review introduces the two main different SIMS configurations time-of-flight SIMS (ToF-SIMS) and nanoscale SIMS (NanoSIMS) as well as some new developments, correlative imaging with other imaging techniques, and applications in neurobiology and cell biology. Briefly, ToF-SIMS uses a pulsed primary ion beam, which ionized the first atomic layers of the sample surface. It allows the detection of element and molecule ions separated by a time-of-flight mass analyzer. In contrast, NanoSIMS employs a continuous high energy and highly focused ion beam that ionizes several nanometers of the sample surface but produces only atomic ions, which are separated with a magnetic sector mass analyzer. A second tutorial review focuses more in detail on ToFSIMS regarding different primary ion beams, signal enhancement methods, identification of biomolecules (lipids, peptides, proteins, and DNA), single cell imaging, and the possibilities to generate threedimensional images. The critical review explores the applications of NanoSIMS in biology and biomedical research. This includes the detection of non-metals such as $\mathrm{N}, \mathrm{P}, \mathrm{S}$, and $\mathrm{Br}$ in cells and tissues. A special application of NanoSIMS is the use of stable isotopes such as ${ }^{2} \mathrm{H},{ }^{13} \mathrm{C},{ }^{15} \mathrm{~N}$, and ${ }^{18} \mathrm{O}$ for tracking of intracellular metabolic processes. Examples are the investigation of nutrient fluxes, nucleic acid synthesis, lipid and glucose metabolism, and protein turnover.

Three research papers focus on ToF-SIMS applications. One paper deals with the detection of zinc the hippocampus of rat brain after traumatic brain injury. Two papers are exploring the possibilities of threedimensional ToF-SIMS imaging; one demonstrates the localization of titanium dioxide nanoparticles in algal biofilm with high lateral resolution of about $100 \mathrm{~nm}$, the other paper presents a study on lipid composition and their 3D distribution in the ovaries of mosquitos.

Although the number of NanoSIMS instruments worldwide that are dedicated to biological applications is relatively limited, two research papers with NanoSIMS applications could be included in this collection. One paper presents the development of fluorinated nanobodies for specific labeling of cellular proteins. Via ${ }^{19} \mathrm{~F}$ detection in NanoSIMS the distribution of various target proteins could be visualized in cells. The other paper shows the combination of subcellular arsenic imaging in seaweed with arsenic speciation analysis by coupling techniques. Surprisingly, most arsenic was located in the cell walls and no arsenic was detected inside the cells. In a further paper an IMS-3f SIMS instrument was used to investigate intracellular calcium stores in pig kidney cells. In addition, the use of the stable ${ }^{44} \mathrm{Ca}$ isotope allowed the imaging of calcium influx in cells.

In summary, this themed collection encompasses the presentation of different SIMS techniques for bioimaging and shows a variety of different biological applications. All papers demonstrate that SIMS bioimaging is not a stand-alone technique but in most cases combined with other imaging tools such as light, fluorescence, and electron microscopy. This reveals the need for correlative imaging and sophisticated data treatment. Other common analytical challenges in SIMS bioimaging concern the development of dedicated sample preparation methods and precise quantification methods. The latter is still difficult due to matrix effects and a lack of matrix-matched standards. The application of chemical imaging by SIMS techniques to biological questions is a rapidly growing field. In future, many more research papers with applications to medicine, pharmacology, toxicology, and environmental sciences are expected.

Finally, I wish to thank all authors who contributed to this themed collection, also the reviewers for their time to evaluate the manuscripts, and the JAAS editorial staff for their work on this collection. I hope the readers will enjoy the articles and that they find many new ideas and stimulation for their own research. 